\title{
Thermostable Cellulases from the Yeast Trichosporon sp.
}

\author{
Hanane Touijer (1D, ${ }^{1,2}$ Najoua Benchemsi, ${ }^{3}$ Mohamed Ettayebi, ${ }^{2}$ Abdellatif Janati Idrissi, ${ }^{2}$ \\ Bouchra Chaouni, ${ }^{4}$ and Hicham Bekkari ${ }^{1,2}$ \\ ${ }^{1}$ Sidi Mohamed Ben Abdellah University, Faculty of Sciences Dhar El Mahraz, Laboratory of Biotechnology, \\ P.O. Box 1796, 30003 Fez-Atlas, Morocco \\ ${ }^{2}$ Sidi Mohamed Ben Abdellah University, Faculty of Sciences Dhar El Mahraz, Biodiversity, \\ Bioenergy \& Environment Research Group (BBE), P.O. Box 1796, 30003 Fez-Atlas, Morocco \\ ${ }^{3}$ Sidi Mohamed Ben Abdellah University, Faculty of Sciences \& Techniques Saiss, Laboratory of Ecology and Environment, \\ P.O. Box 1796, 30000 Fez, Morocco \\ ${ }^{4}$ Laboratory of Plant and Microbial Biotechnology, Biodiversity and Environment, Faculty of Sciences, \\ University Mohamed V in Rabat, 10000 Rabat, Morocco \\ Correspondence should be addressed to Hanane Touijer; hananetou@gmail.com
}

Received 8 January 2019; Accepted 20 March 2019; Published 17 April 2019

Academic Editor: Raffaele Porta

Copyright (C) 2019 Hanane Touijer et al. This is an open access article distributed under the Creative Commons Attribution License, which permits unrestricted use, distribution, and reproduction in any medium, provided the original work is properly cited.

Objectives. Identification of cellulolytic microorganisms is of great interest to the hydrolysis of cellulosic biomass. This study focuses on the identification of cellulolytic yeasts and the optimization of cellulase activities produced by the best performing isolate. Results. 30 cellulolytic yeast isolates were selected. Enzymes produced by an isolate from the Trichosporon genus showed the property to hydrolyze different substrates: carboxymethyl cellulose (CMC), cellulose fiber, and filter paper (FP). The optimum measured temperature was $55^{\circ} \mathrm{C}$ for CMCase and $60^{\circ} \mathrm{C}$ for FPase. The optimal pH was 5 for CMCase and 4 to 6 for FPase. The effect of the substrates concentration showed that the best activities were obtained at $100 \mathrm{mg} / \mathrm{mL}$ CMC or FP. The highest activities were 0.52 for the CMCase and 0.56 for the cellulase fiber at $10 \mathrm{~min}$ incubation, $0.44 \mathrm{IU} / \mathrm{mL}$ at $15 \mathrm{~min}$ incubation, and $24 \mathrm{~h}$ FPase preincubation. Conclusion. Cellulases produced by the studied yeast are capable of hydrolyzing soluble and insoluble substrates at elevated temperatures and at a wide $\mathrm{pH}$ range. They are considerable interest in the production of fermentable sugars from lignocellulosic substrates.

\section{Introduction}

Cellulose is the most important constituent of the plant cell wall [1]. This polymer is widely used in many industry sectors such as agrifood, paper mill, and bioethanol production [2]. Interestingly, bioethanol made from cellulosic biomass attracts lots of attention as a biofuel, with economic advantages and minimal impact on the environment [1]. Bioethanol production requires four major steps: biomass pretreatment, cellulose hydrolysis, fermentation, and distillation [3]. Cellulose hydrolysis to glucose could be performed by chemical, physical, or enzymatic processes. Enzymatic hydrolysis is the most used in the industry because of its high yields with fewer unwanted side products [4]. It is achieved by a simultaneous action of three enzymes: endo- $\beta$-glucanase (EC 3.2.1.4), exo$\beta$-glucanase (EC 3.2.1.91), and $\beta$-glucosidase (EC 3.2.1.21)
[5]. Fungi and bacteria are potential producers of cellulase enzymes $[6,7]$. Nowadays, yeast cellulases gain interest, as they are active in a wide $\mathrm{pH}$ range and at high temperatures $[8,9]$. Indeed, yeasts can produce thermostable cellulase, undenatured at temperatures greater than or equal to $70^{\circ} \mathrm{C}$ $[10,11]$. They can be used in the processes of saccharification of lignocellulose into fermentable sugars for the production of bioethanol.

This study aims to isolate yeast strains from the gastrointestinal tract of the coprophage "Gymnopleurus sturmi" capable of producing cellulases and then to optimize the measurement conditions of cellulase activities.

\section{Materials and Methods}

2.1. Microorganisms and Culture Conditions. The selection of cellulose isolates in yeasts was determined by growing 
them on Mandels and Weber medium (MW, 1969), which was based on the carboxymethyl cellulose (CMC) as a unique source of carbon and energy. The incubation was performed at $37^{\circ} \mathrm{C}$ for 48 to 72 hours. The cellulase activity was revealed by the addition of a solution of $1 \%$ Congo red, which binds to the polymers of cellulose. After 15 to 20 minutes, the dishes were washed with a solution of $\mathrm{NaCl}(1 \mathrm{M})$. The rise/appearance of a light halo around the colonies indicates that the incorporated CMC in the medium was degraded by the cellulase secreted by the isolates; the latter are called "cellulase +".

2.2. Molecular Characterization. The molecular characterization was performed by carrying out sequencing of DNA ITS region. This region was amplified with ITS1 and ITS4 pair of primers. A $25 \mu \mathrm{L}$ of the PCR reaction mixture was prepared with $0.2 \mu \mathrm{l}$ of Taq $(0.01 \mathrm{U} / \mu \mathrm{l}), 0.625 \mu \mathrm{l}$ of each primer, $1 \mu \mathrm{l}$ of dNTPs $(0.2 \mathrm{mM}), 5 \mu \mathrm{l}$ of Buffer (1X), $1.75 \mu \mathrm{l} \mathrm{MgCl} 2(1.5 \mathrm{mM})$, $2 \mu \mathrm{l}$ d'ADN, and $13.8 \mu \mathrm{l}$ of water ultrapure. Amplification reaction was performed in the TECHNE thermocycler. The sequences were generated by ABI PRISM 3130XL (Applied Biosystems) as genetic analyzer. Then the results were processed by the BioEdit software and the nucleotide sequence was analyzed using the Basic Local Alignment Search Tool (BLAST).

2.3. Evaluation of Cellulase Enzymes Production by Trichosporon sp. The characterization and optimization of cellulase activities are carried out on a yeast isolate that belongs to the genus Trichosporon, which was the most powerful with regard to the hydrolysis halo of CMC diameter, in a qualitative test. The MW medium was used for the production of these enzymes. The inoculum of the studied yeast was added to the culture medium. Then, the mixture was incubated at $37^{\circ} \mathrm{C}$ for 4 days, the cell suspension was centrifuged $(6000 \mathrm{~g}, 10 \mathrm{~min})$, and the recovered supernatant was used as an enzymatic medium for the measurement of cellulase activities.

2.4. Measurement of Cellulase Activities. For CMCase and cellulase fiber activity, $0.5 \mathrm{~mL}$ of cellulosic substrates, CMC, or $1 \%(\mathrm{w} / \mathrm{v})$ cellulose fiber, dissolved in sodium acetate buffer $(0.1 \mathrm{M}, \mathrm{pH} 4.8)$, was preincubated for $10 \mathrm{~min}$ at $50^{\circ} \mathrm{C}$. Then $0.5 \mathrm{~mL}$ of the enzyme medium was added, and the mixture was incubated at $50^{\circ} \mathrm{C}$ for $30 \mathrm{~min}$.

For FPase activity, $50 \mathrm{mg}$ Whatman No. 1 filter paper $(1 \times$ $6 \mathrm{~cm}$ pieces), added to $1 \mathrm{~mL}$ acetate buffer $(0.1 \mathrm{M}, \mathrm{pH} 4.8)$, was preincubated at $50^{\circ} \mathrm{C}$ for $10 \mathrm{~min}$. Then, $0.5 \mathrm{~mL}$ of the enzyme medium was added. The mixture was incubated at $50^{\circ} \mathrm{C}$ for $60 \mathrm{~min}$.

The reduction of the sugar released into the reaction mixture was determined by the dinitrosalicylic acid (DNS) method [12].

2.5. Effects of the Temperature and $p H$ on CMCase and FPase Activities. The impact of temperature on the activity of the enzymes CMCase and FPase was evaluated at a $4.8 \mathrm{pH}$ and incubation at different temperatures ranging from 20 to $100^{\circ} \mathrm{C}$ of the reaction mixtures. The study of the effect of $\mathrm{pH}$ on the variation of the enzymatic activities was carried out by incubating the reaction mixtures at $50^{\circ} \mathrm{C}$, over a $\mathrm{pH}$ ranging from 3 to 9.

2.6. Effect of Substrate Concentration on CMCase and FPase Activities. The cellulase activity variation in terms of the substrate concentration was tested for different CMC concentrations, ranging from 0 to $100 \mathrm{mg} / \mathrm{mL}$ and for $\mathrm{FP}$ quantities ranging from 10 to $100 \mathrm{mg}$ under the following conditions $\left(\mathrm{pH} 4.8, \mathrm{~T}^{\circ}\right.$ at $\left.50^{\circ} \mathrm{C}\right)$.

2.7. Kinetics of CMCase and FPase. The kinetic of the studied enzymes was determined by measuring the concentration of glucose released during the hydrolysis of the various substrates (CMC, FP) at incubation times ranging from 10 to $60 \mathrm{~min}$.

The optimization of the hydrolysis activity of the filter paper was carried out after preincubation $(0,30,60 \mathrm{~min}$, and $24 \mathrm{~h}$ ) of the filter paper in the acetate buffer (0.1M, pH 4.8).

2.8. Calculation Method. The released glucose concentration was used to calculate the cellulase enzyme rates after hydrolysis of the cellulosic substrates. The international unit (IU) of cellulase activity is defined as the amount of enzyme which releases $1 \mu \mathrm{mol}$ of glucose per minute [13].

Cellulase activity (IU/mL)

$$
=\frac{[\text { Glucose released }] \mu \text { mole }}{0.5 \mathrm{~mL} \text { of enzymatic medium } \times \text { Incubation time }(\mathrm{min})}
$$

The protein concentration was measured according to the method of Bradford (1976). The specific activity was determined by the ratio of the enzyme's catalytic concentration to the protein concentration (IU/mg protein).

$$
\text { Specific activity IU } / \mathrm{mg}=\frac{\text { Cellulase activity IU } / \mathrm{mL}}{\text { [protein }] \mathrm{mg} / \mathrm{mL}}
$$

\section{Results and Discussion}

3.1. Screening of Yeasts Isolates for Cellulases Production. Isolation of yeasts from the digestive tract of the coprophage «gymnopleurus sturmi» resulted in a collection of 55 isolates, 30 of which was cellulosic. Among these isolates, an isolate with very high hydrolysis activity has been optimized for its CMCase and FPase activities. The DNA sequence analysis of the ITS region helped us to identify the isolate that was from the genus Trichosporon.

3.2. Hydrolysis of Different Cellulosic Substrates. The cellulases produced by the selected yeast were made in evidence by the incubation of the enzyme medium with different substrates, namely, CMC, cellulose fiber, or filter paper. Results of Figure 1 show that the yeast Trichosporon sp. has a CMCase activity, fiber cellulase, and FPase of $0.16 \mathrm{IU} / \mathrm{mL}, 0.09 \mathrm{IU} / \mathrm{mL}$, and $0.07 \mathrm{IU} / \mathrm{mL}$, respectively. Hence, the enzymes produced 


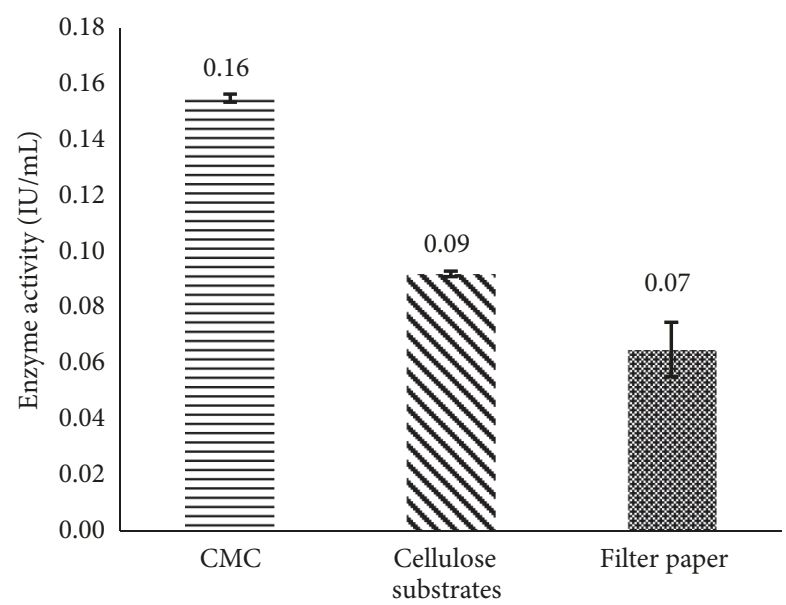

Figure 1: Hydrolysis of cellulosic substrates.

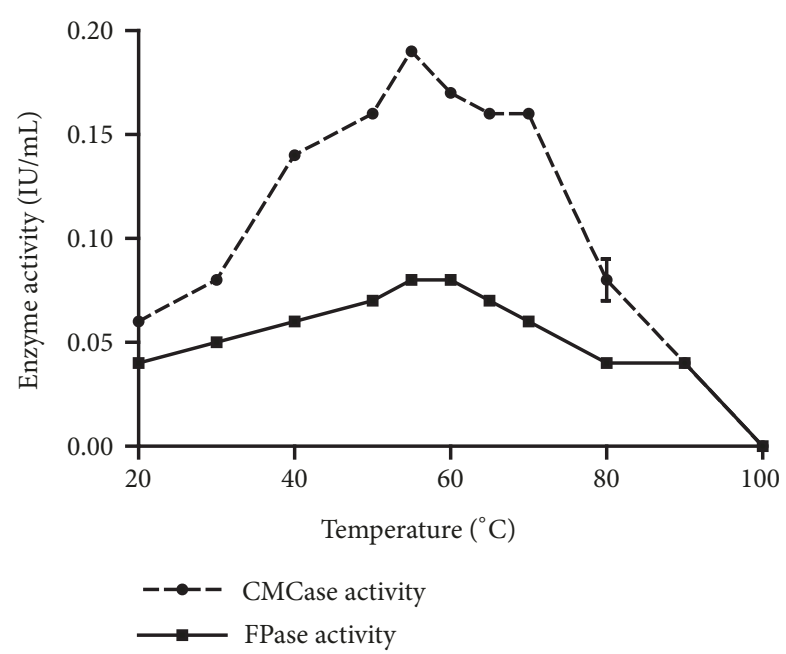

FIGURE 2: Effect of temperature variation of incubation on CMCase and FPase activities ( $\mathrm{pH} 4.8,10 \mathrm{mg} / \mathrm{mL} \mathrm{CMC}$, and $50 \mathrm{mg} / \mathrm{mL}$ filter paper).

are capable of hydrolyzing soluble CMC and insoluble cellulose substrates such as cellulose fiber and filter paper. Studies on Trichosporon laibachii yeast have shown that despite its CMCase activity, this strain is unable to hydrolyze insoluble substrates like cellulose fiber and filter paper [9]. Similar results are also observed on fungi, as Lucas et al. (2001) detected no cellulase able to hydrolyze insoluble substrates.

The characterization of CMCase and FPase activities was carried out to determine the optimal conditions for measuring these activities, namely, temperature, $\mathrm{pH}$, substrate concentration, and the reaction time.

3.3. Effect of Temperature on CMCase and FPase Activities. Results of Figure 2 show that CMCase and FPase are active at temperatures ranging from 20 to $90^{\circ} \mathrm{C}$, with optimal temperature at $55^{\circ} \mathrm{C}$ : the $\mathrm{CMCase}$ activity was $0.19 \mathrm{IU} / \mathrm{mL}$ and FPase activity was $0.08 \mathrm{IU} / \mathrm{mL}$ at $60^{\circ} \mathrm{C}$. The residual CMCase and FPase activities were at $44.44 \%$ and $50 \%$, respectively,

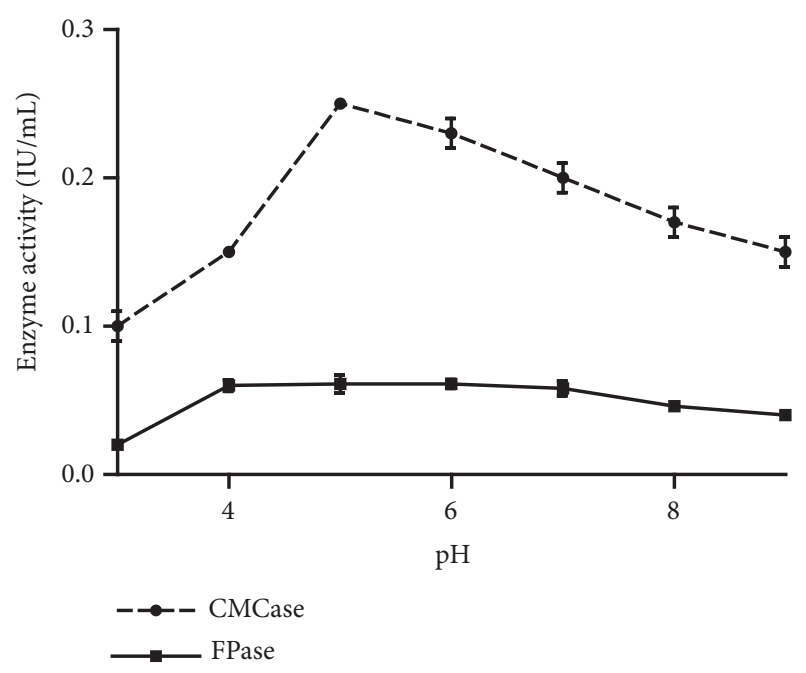

FIGURE 3: Effect of $\mathrm{pH}$ on CMCase and FPase activity (temperature $50^{\circ} \mathrm{C}, 10 \mathrm{mg} / \mathrm{mL} \mathrm{CMC}$, and $50 \mathrm{mg} / \mathrm{mL}$ filter paper).

even at a higher temperature as $80^{\circ} \mathrm{C}$. Indeed, the strain of the studied yeast Trichosporon sp. is able to hydrolyze the cellulosic substrates even at high temperatures. In a similar work on fungi, such as Aspergillus niger and Penicillium decumbens, the maximum CMCase activity is observed at $50^{\circ} \mathrm{C}$ [14]. On the other hand, Nawaz S. et al. [15] found that the optimal temperature of the CMCase of the fungus Trichoderma harzianum is only $30^{\circ} \mathrm{C}$

3.4. Effect of pH on CMCase and FPase Activities. Results of Figure 3 show that the cellulases activity of the Trichosporon sp. yeast has a wide $\mathrm{pH}$ range, ranging from 3 to 9 . The optimal $\mathrm{pH}$ of the CMCase was $5(0.25 \mathrm{IU} / \mathrm{mL})$, while that the FPase activity was maximal and stable $(0.06 \mathrm{IU} / \mathrm{mL})$ at $\mathrm{pH}$ varying from 4 to 7 . The increase or the decrease of the $\mathrm{pH}$ values on either side of the optimal values was not followed by a rapid loss of activity, since the residual activities at $\mathrm{pH} 9$ were $60 \%$ and $66.7 \%$, respectively, for the CMCase and FPase activities. In addition, these enzymes retain at $\mathrm{pH}$ of 3 more than $40 \%$ and $26.7 \%$ of their activities, respectively (Figure 3 ). Thus, the cellulase enzymes produced by the yeast studied can be considered as tolerant to acidic and alkaline conditions. These results corroborate with those of Oikawa et al. [16] who showed that the yeast CMCase Rhodotorula glutinis $\mathrm{KuJ}$ is active at $\mathrm{pH}$ ranging from 2 to 7 with an optimal $\mathrm{pH}$ of 4.5 . Geimba et al. (1999) have also shown that the CMCase of the fungus Bipolaris sorokiniana has a maximum activity at $\mathrm{pH} 5$ but is inactive at $\mathrm{pH}$ of 3 . The cellulases of the fungi Aspergillus niger and Penicillium decumbens [14] also have an optimal $\mathrm{pH}$ of 5 .

3.5. Effect of Substrates Concentration on CMCase and FPase Activities. The effect of the substrates concentration was also studied in order to optimize cellulase activities. The CMCase reaches a rate of $0.4 \mathrm{IU} / \mathrm{mL}$ at a concentration of $100 \mathrm{mg} / \mathrm{mL}$ of CMC and the FPase activity reaches $0.1 \mathrm{IU} / \mathrm{mL}$ at $100 \mathrm{mg} / \mathrm{mL}$ of the filter paper (Figures $4(\mathrm{a})$ and $4(\mathrm{~b})$ ). These 


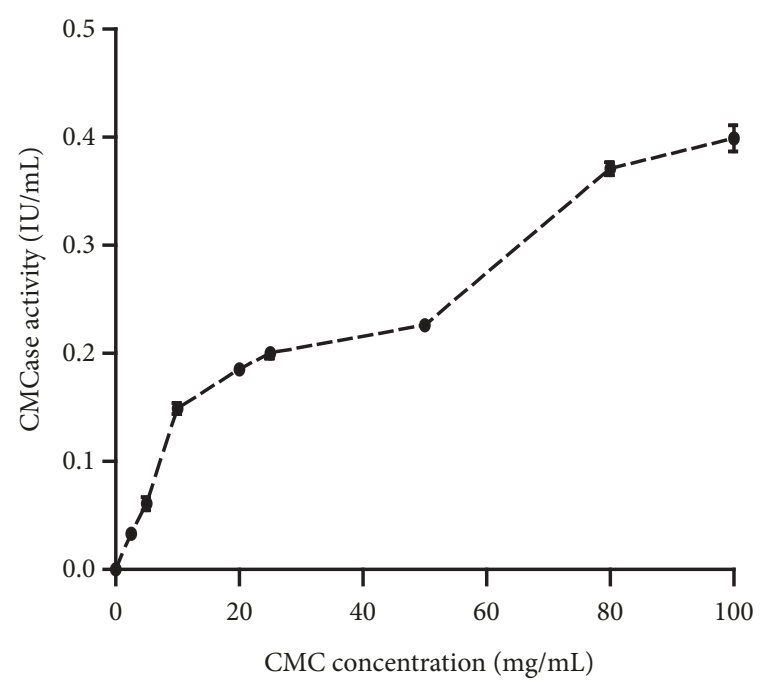

(a)

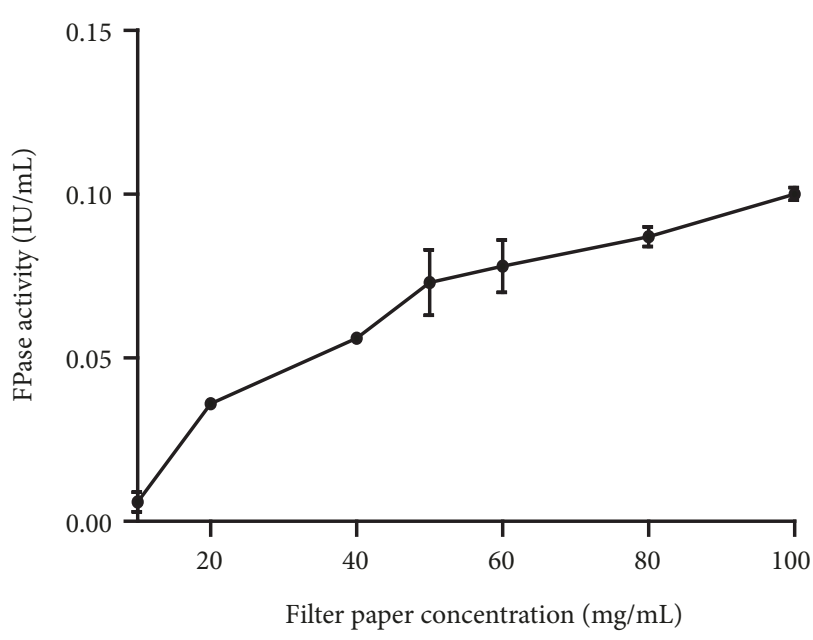

(b)

FIGURE 4: (a) Effect of CMC concentration on CMCase activity and (b) effect of filter paper concentration on FPase activity (pH 4.8; temperature $\left.50^{\circ} \mathrm{C}\right)$.

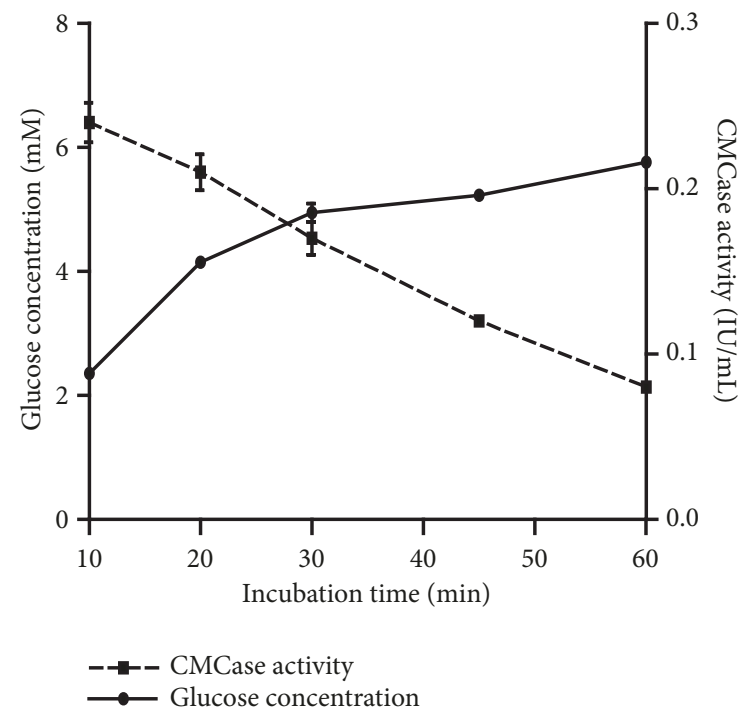

(a)

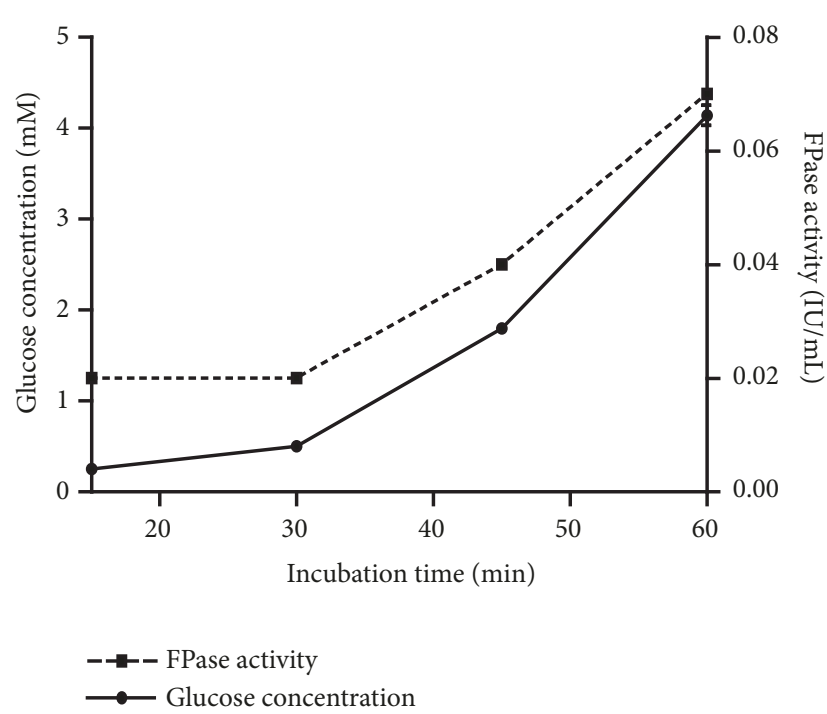

(b)

Figure 5: (a) Kinetics of CMCase ( $\mathrm{pH} \mathrm{4,8,} \mathrm{temperature} 50^{\circ} \mathrm{C}$, and $10 \mathrm{mg} / \mathrm{mL} \mathrm{CMC).} \mathrm{(b)} \mathrm{Kinetics} \mathrm{of} \mathrm{FPase} \mathrm{(} \mathrm{pH} 4.8$, temperature $50^{\circ} \mathrm{C}$, and 50 $\mathrm{mg} / \mathrm{mL}$ filter paper).

results are in agreement with those of Saliu and Sani. [14], who showed that the CMCase activity of Aspergillus niger and Penicillium decumbens mushrooms was also maximal at a concentration of $100 \mathrm{mg} / \mathrm{mL}$ of CMC.

3.6. Kinetics of CMCase and FPase. The amount of the released glucose and the CMCase and FPase activities was determined using different incubation times. Results show in Figure 5(a) that the concentration of the released glucose increases with the incubation time in the presence of CMC from 10 to $30 \mathrm{~min}$, and the maximum CMCase activity $(0.24 \mathrm{IU} / \mathrm{mL})$ was observed after $10 \mathrm{~min}$ of incubation. The best amount of the released glucose during the hydrolysis of the filter paper was $4.14 \mathrm{mM}$, after $60 \mathrm{~min}$ of incubation and the maximum FPase activity was $0.07 \mathrm{IU} / \mathrm{mL}$ (Figure 5(b)).

3.7. Optimization of Preincubation Time of the Filter Paper on FPase Activity. Figure 6 demonstrates the presence of a $30 \mathrm{~min}$ phase where the FPase activity remains low. In order to reduce the latency time, preincubations of the filter paper in the buffer were performed at different times. When the preincubation time was $0,10,30$, or $60 \mathrm{~min}$, the best concentration of glucose $(5.6 \mathrm{mM})$ and the highest FPase activity $(0.1 \mathrm{IU} / \mathrm{mL})$ was recorded only after $60 \mathrm{~min}$. The 

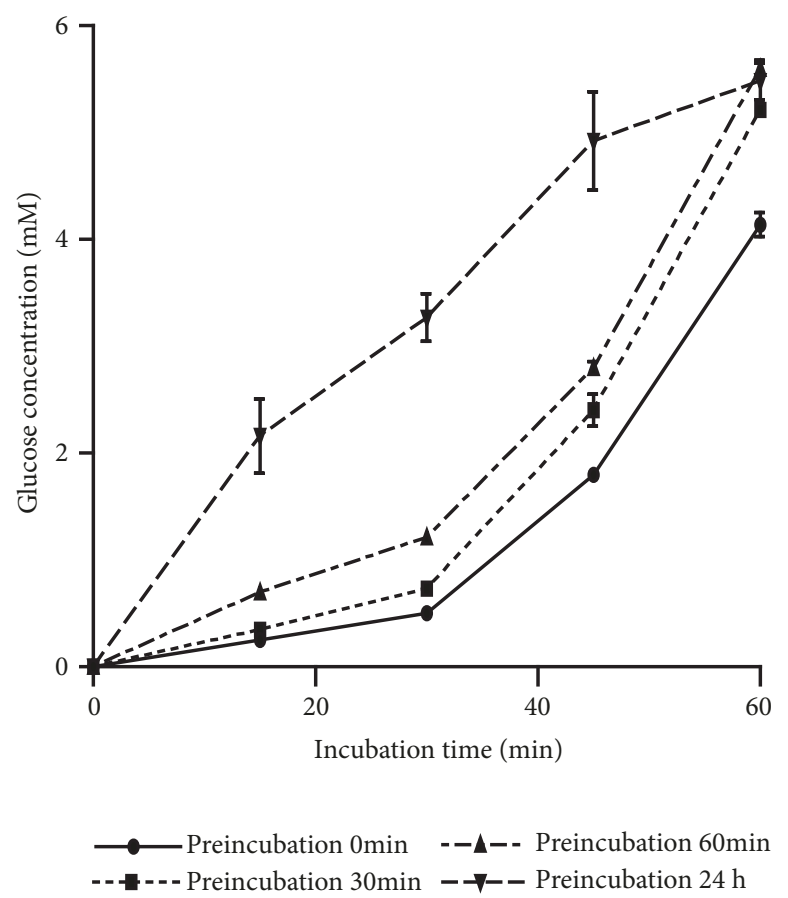

(a)
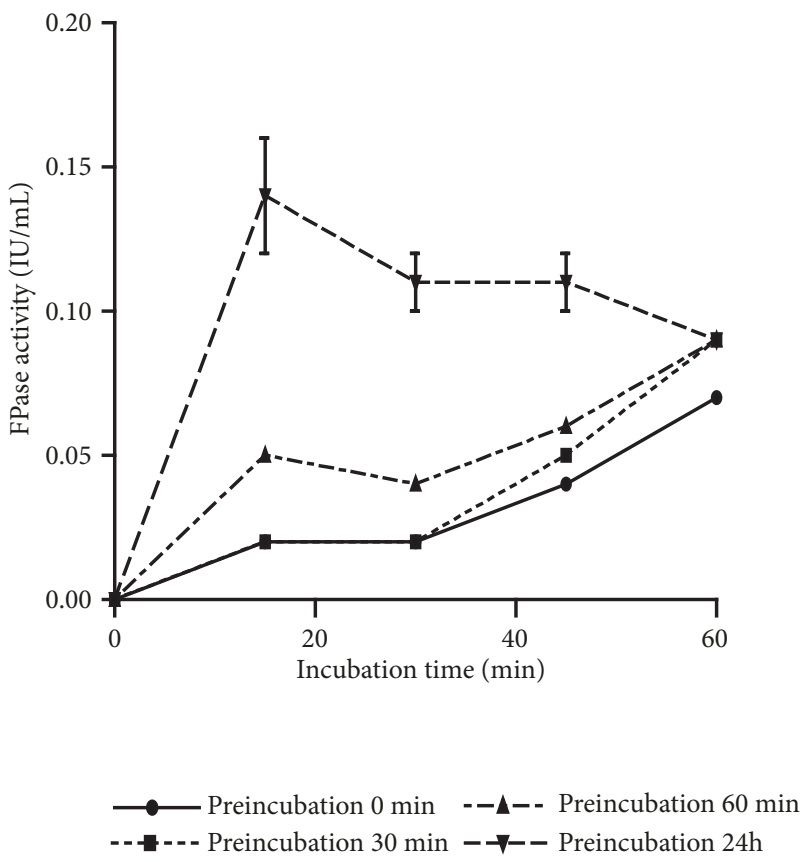

(b)

Figure 6: (a) Effect of preincubation time of the filter paper on glucose concentration; (b) the kinetics of FPase (pH 4.8 , temperature $50^{\circ} \mathrm{C}$, and $50 \mathrm{mg} / \mathrm{mL}$ filter paper).

TABLE 1: Optimal activities of cellulases enzymes (Acetate buffer pH 5, Substrate concentration; $50 \mathrm{mg} / \mathrm{mL}$ of CMC or cellulose Fiber and $80 \mathrm{mg} / \mathrm{mL}$ of filter paper).

\begin{tabular}{lcccccc}
\hline & \multicolumn{2}{c}{ CMCase } & \multicolumn{2}{c}{ FPase } & \multicolumn{2}{c}{ Fibre cellulase } \\
Temperature $\left({ }^{\circ} \mathrm{C}\right)$ & Activity $(\mathrm{IU} / \mathrm{mL})$ & $\begin{array}{c}\text { Specific activity } \\
\mathrm{U} / \mathrm{mg})\end{array}$ & Activity $(\mathrm{IU} / \mathrm{mL})$ & $\begin{array}{c}\text { Specific activity } \\
(\mathrm{U} / \mathrm{mg})\end{array}$ & $\begin{array}{c}\text { Activity }(\mathrm{IU} / \mathrm{mL}) \\
\text { Specific activity } \\
(\mathrm{U} / \mathrm{mg})\end{array}$ \\
\hline 50 & $0.49 \pm 0.02$ & $12.25 \pm 0.1$ & $0.38 \pm 0.03$ & $9.5 \pm 0.6$ & $0.44 \pm 0.04$ & $11 \pm 0.4$ \\
55 & $0.52 \pm 0.03$ & $13 \pm 0.2$ & $0.39 \pm 0.02$ & $9.75 \pm 0.4$ & $0.47 \pm 0.02$ & $11.75 \pm 0.3$ \\
60 & $0.5 \pm 0.01$ & $12.5 \pm 0.2$ & $0.44 \pm 0.01$ & $11 \pm 0.1$ & $0.48 \pm 0.03$ & $12 \pm 0.3$ \\
65 & $0.48 \pm 0.04$ & $12 \pm 0.3$ & $0.3 \pm 0.05$ & $7.5 \pm 1.3$ & $0.56 \pm 0.06$ & $14 \pm 0.7$ \\
70 & $0.47 \pm 0.004$ & $11.75 \pm 0.4$ & $0.29 \pm 0.07$ & $7.25 \pm 0.1$ & $0.34 \pm 0.002$ & $8.5 \pm 0.5$ \\
\hline
\end{tabular}

best FPase activity $(0.14 \mathrm{IU} / \mathrm{mL})$ at 24 -hour preincubation of the filter paper was obtained after 15 minutes. Hence, it was extremely interesting to apply the 24-hour preincubation of the filter paper in order to increase the FPase activity, which was probably due to a better absorption of the enzyme medium through the filter paper.

\subsection{Evaluation of Cellulases Activities under Optimal Condi-} tions. Results of the evaluation of cellulase activities under optimal conditions showed that the CMCase activity was $0.52 \mathrm{IU} / \mathrm{mL}$ at $10 \mathrm{~min}$ of incubation at temperatures of $55^{\circ} \mathrm{C}$; the FPase activity was maximal $(0.44 \mathrm{IU} / \mathrm{mL})$ at $60^{\circ} \mathrm{C}$, under 15 min of incubation (Table 1). The maximum hydrolysis activity of the cellulose fiber was about $0.56 \mathrm{IU} / \mathrm{mL}$ at $10 \mathrm{~min}$ at the temperatures of $65^{\circ} \mathrm{C}$. The specific activity was 12.5 , 11 , and $14 \mathrm{U} / \mathrm{mg}$ of protein for CMCase, cellulase fiber, and FPase, respectively. The activities of these enzymes after optimization were three times higher for CMCase and five times with regard to FPase and cellulase fiber.

Industrial processes for the hydrolysis of cellulosic material into fermentable sugar are carried out under particular physical and chemical conditions, at the optimum values of the activity of available commercial enzymes. The yeast enzymes of this study are of considerable interest because of their activity at different temperatures and their ability to hydrolyze different soluble and insoluble cellulosic substrates. In fact, these enzymes may have potential applications in the treatment of agricultural waste and the bioremediation of cellulosic materials for sustainable bioethanol production.

\section{Conclusion}

In this study, 30 isolates of cellulosic yeasts were selected. The optimization of cellulase activities was performed on 
Trichosporon sp. genus. The results showed that this strain has a great potential to be used in the enzymatic saccharification of soluble (CMC) and insoluble (cellulose fiber and filter paper) cellulosic substrates at a wide $\mathrm{pH}$ range, with an optimum at 5 , and at high temperatures of 55 to $70^{\circ} \mathrm{C}$.

\section{Data Availability}

The data used to support the findings of this study are available from the corresponding author upon request.

\section{Disclosure}

A part of this work has been presented as oral communication at MICROBIOME FOR HEALTH II-2018-colloquium October 2018 in Sidi Mohamed Ben Abdellah University, Faculty of Sciences Dhar Mahraz.

\section{Conflicts of Interest}

The authors declare that they have no conflicts of interest.

\section{References}

[1] O. C. Amadi, N. Onyema, T. N. Nwagu, A. N. Moneke, B. N. Okolo, and R. C. Agu, "Evaluating the potential of wild cocoyam, caladium bicolor, for ethanol production using indigenous fungal isolates," Procedia Environmental Sciences, vol. 35, pp. 809-817, 2016.

[2] D. Mortabit, M. Zyani, A. Haggoud et al., "Carboxymethyl cellulase production by moroccan bacillus isolates," Moroccan Journal of Biology, vol. 1, no. 6-7, pp. 43-49, 2010.

[3] R. Saini, J. K. Saini, M. Adsul et al., "Enhanced cellulase production by Penicillium oxalicum for bio-ethanol application," Bioresource Technology, vol. 188, pp. 240-246, 2015.

[4] N. J. Parry, D. E. Beever, E. Owen, I. Vandenberghe, J. Van Beeumen, and M. K. Bhat, "Biochemical characterization and mechanism of action of a thermostable beta-glucosidase purified from Thermoascus aurantiacus," The Biochemical Journal, vol. 353, Article ID 3530117, pp. 117-127, 2001.

[5] X. Yu, Y. Liu, Y. Cui et al., "Measurement of filter paper activities of cellulase with microplate-based assay," Saudi Journal of Biological Sciences, vol. 23, no. 1, pp. S93-S98, 2016.

[6] J. Thongekkaew and J. Kongsanthia, "Screening and identification of cellulase producing yeast from rongkho forest, ubon ratchathani university," Horizon Research Publishing, vol. 4, no. 3, Article ID 040301, pp. 29-33, 2016.

[7] E. A. Bayer, R. Lamed, and M. E. Himmel, "The potential of cellulases and cellulosomes for cellulosic waste management," Current Opinion in Biotechnology, vol. 18, no. 3, pp. 237-245, 2007.

[8] H. Chen and X. Fu, "Industrial technologies for bioethanol production from lignocellulosic biomass," Renewable and Sustainable Energy Reviews, vol. 57, pp. 468-478, 2016.

[9] E. C. Giese, K. J. Dussßn, M. Pierozzi et al., "Cellulase production by trichosporon laibachii," Orbital - The Electronic Journal of Chemistry, vol. 9, no. 4, pp. 271-278, 2017.

[10] M. K. Bhat, "Cellulases and related enzymes in biotechnology," Biotechnology Advances, vol. 18, no. 5, pp. 355-383, 2000.
[11] J. Choudhary, S. Singh, and L. Nain, "Thermotolerant fermenting yeasts for simultaneous saccharification fermentation of lignocellulosic biomass," Electronic Journal of Biotechnology, vol. 21, pp. 82-92, 2016.

[12] G. L. Miller, "Use of dinitrosalicylic acid reagent for determination of reducing sugar," Analytical Chemistry, vol. 31, no. 3, pp. 426-428, 1959.

[13] T. K. Ghose, "Measurement of cellulase activities," Pure and Applied Chemistry, vol. 59, no. 2, pp. 257-268, 1987.

[14] B. K. Saliu and A. Sani, "Bioethanol potentials of corn cob hydrolysed using cellulases of Aspergillus niger and Penicillium decumbens," Excli Journal, vol. 11, pp. 468-479, 2012.

[15] S. Nawaz, M. A. Malana, I. Naheed, H. Samia, M. I. Ghori, and A. Jamil, "Life and social sciences kinetic study of carboxymethyl cellulase from trichoderma harzianum," Pakistan Journal of Life and Social Sciences, vol. 4, no. 1-2, pp. 15-19, 2006.

[16] T. Oikawa, Y. Tsukagawa, and K. Soda, "Endo-ß-glucanase secreted by a psychrotrophic yeast: purification and characterization," Bioscience, Biotechnology, and Biochemistry, vol. 62, no. 9, pp. 1751-1756, 1998. 


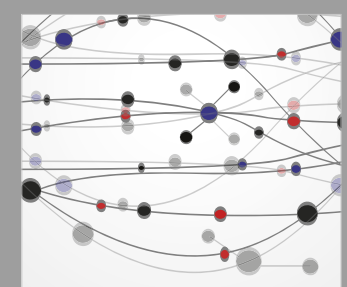

The Scientific World Journal
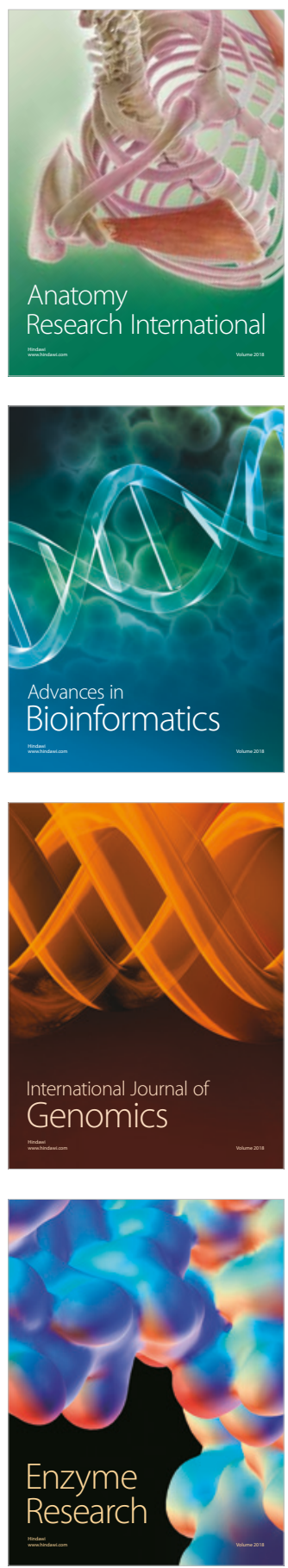
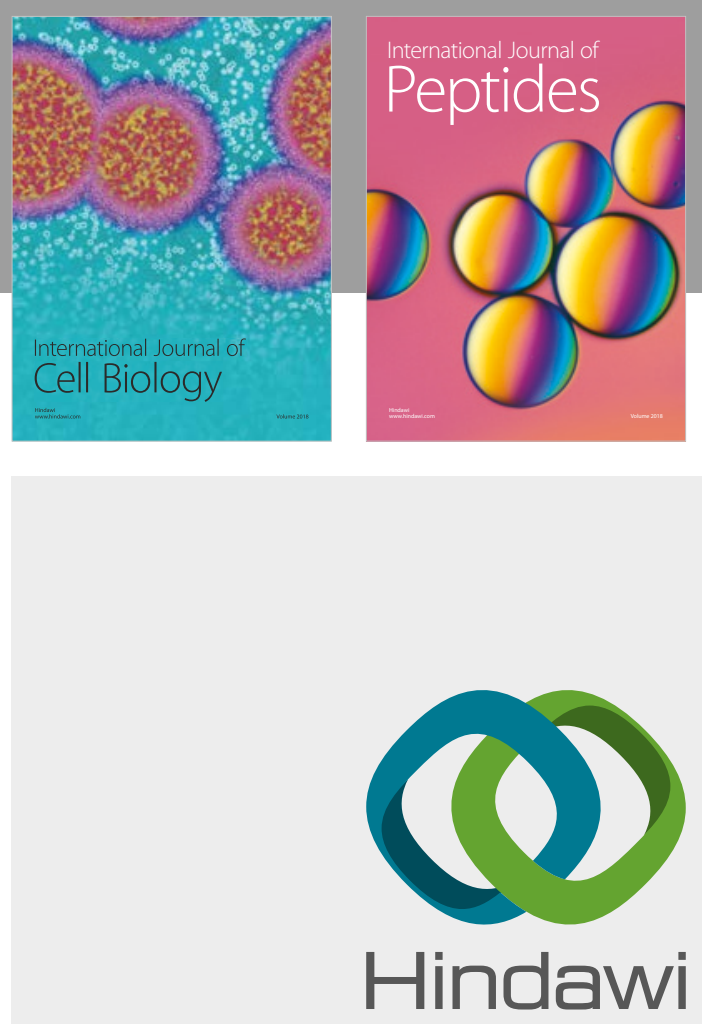

Submit your manuscripts at

www.hindawi.com
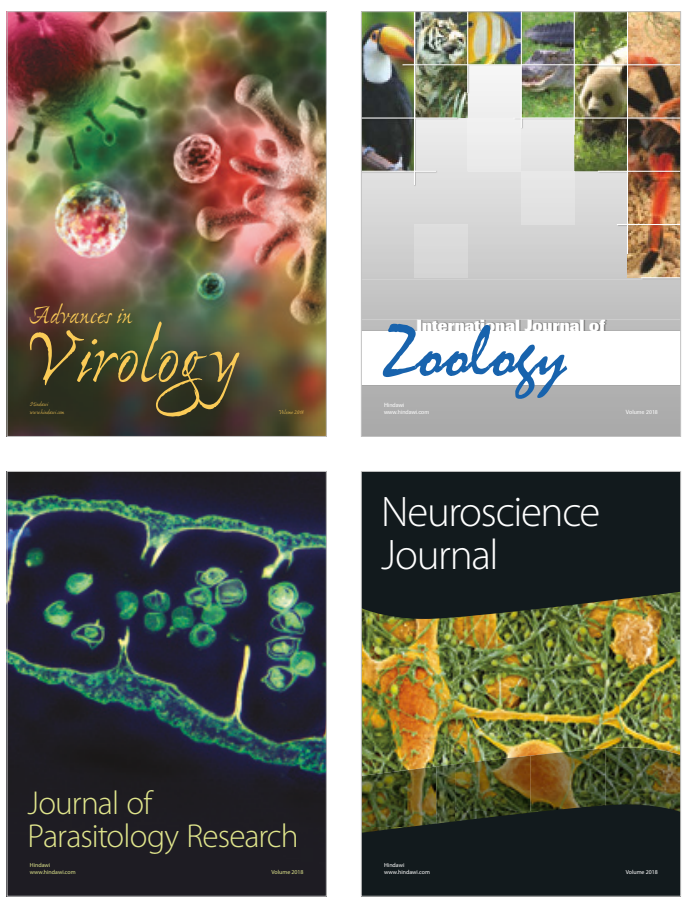
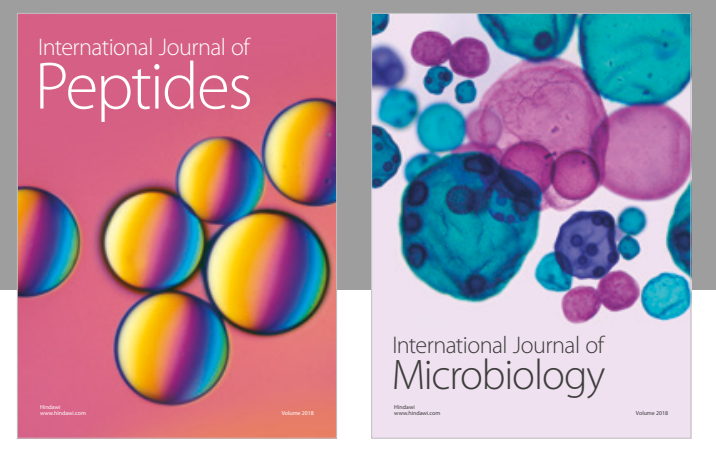

nternational Journal of Microbiology
Journal of
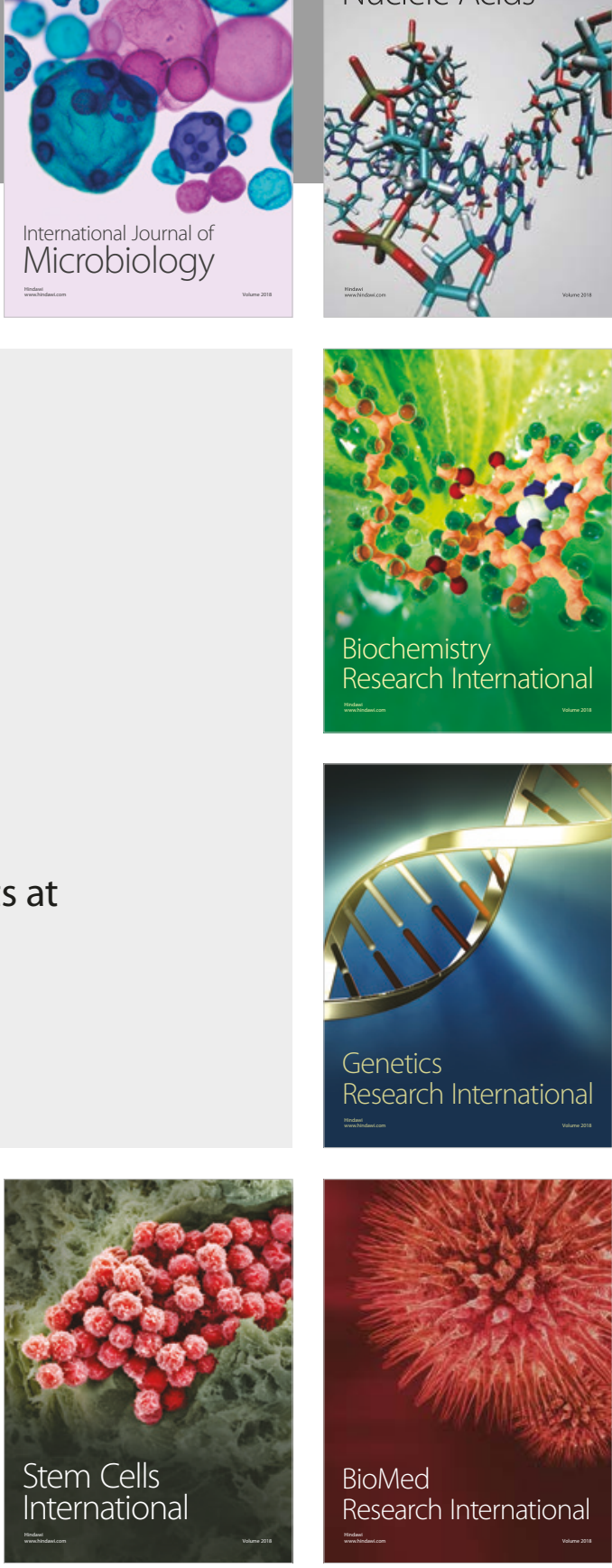
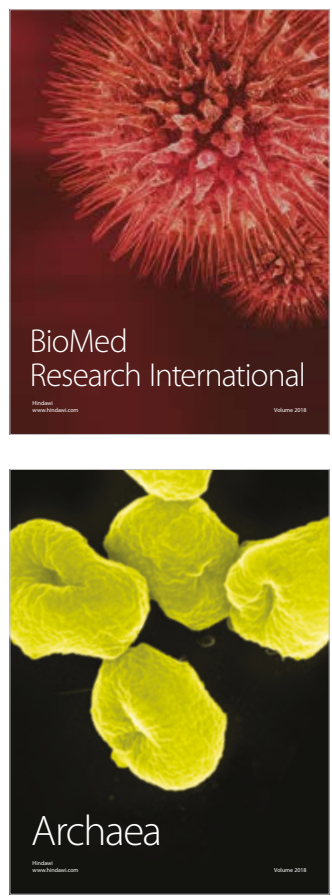